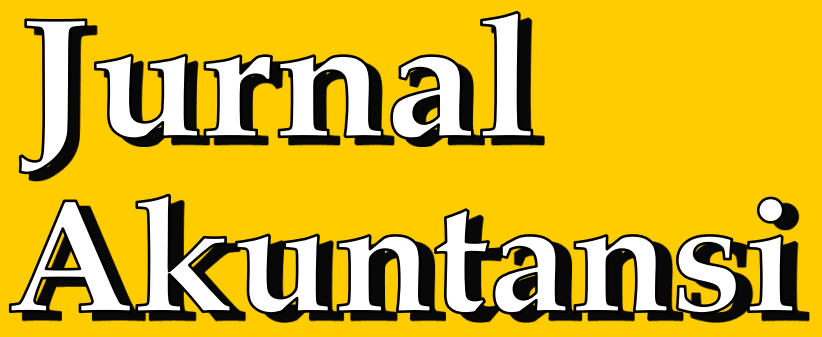

\title{
dam Kenangan
}

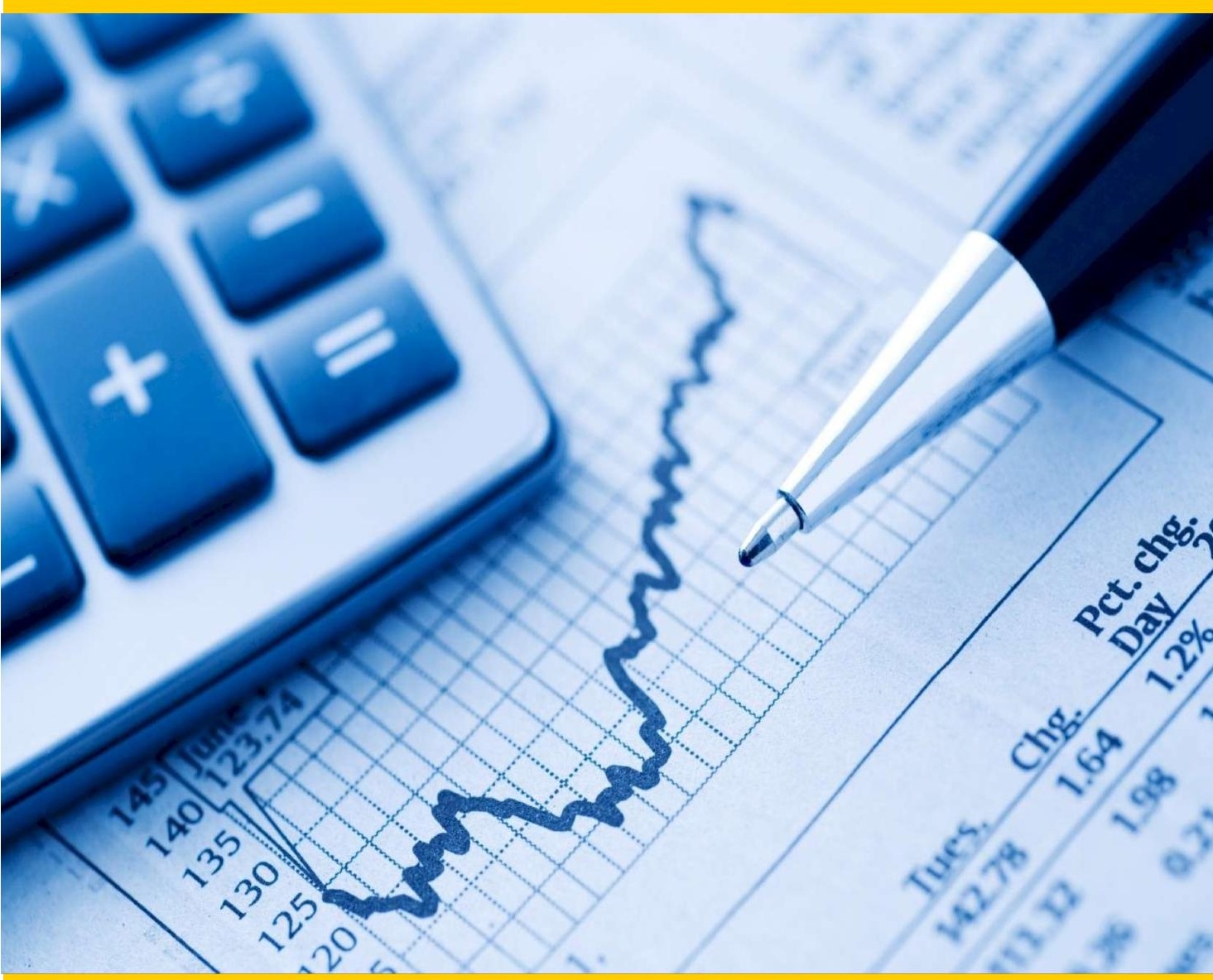

Diterbitkan oleh:

Program Studi Akuntansi

Fakultas Ekonomi dan Bisnis, Universitas Malikussaleh 


\section{EDITOR IN CHIEF}

Indrayani, SE., M.Si., Ak., CA

Universitas Malikussaleh

\section{MANAGING EDITOR}

Nur Afni Yunita, SE., M.Si

Universitas Malikussaleh

\section{ASSOCIATED EDITOR}

Pasca Dwi Putra, SE., M.Si

Universitas Negeri Medan

Yani Prihatina Eka Furda, SE., M.Si

Universitas Iskandar Muda

Budianto, SE., M.Si

Universitas Teuku Umar

Lakharis Inuzula, SE., M.Si., Ak Universitas Islam Kebangsaan

Indonesia

Isra Maulina, SE., M.Si

IAIN Lhokseumawe

\section{COPY EDITORS}

Muhammad Yusra, SE., M.Si

Universitas Malikussaleh

\section{LAYOUT EDITORS}

Dy Ilham Satria, SE., M.Si

Universitas Malikussaleh

Nurhasanah, SE., M.Si., Ak

Universitas Malikussaleh

PROOFREADER \& LANGUAGE EDITORS

Marina, S.Pdi., M.Ed

Universitas Malikussaleh

Hanif, S.Pd., M.Pd

Universitas Malikussaleh

\section{REVIEWER}

Dr. Jumadil Saputra (Universitas Malaysia Terengganu)

Dr. Jufri Darma, SE., M.Si., Ak., CA (Universitas Negeri Medan)

Dr. Ruhul Fitrios, SE., M.SI (Universitas Riau)

Dr. Husaini, SE., M.Si., AK., CA (Universitas Bengkulu)

Dr. Fazli Syam BZ., SE., M.Si., Ak., CA (Universitas Syiah Kuala)

Dr. Muhammad Arfan, SE., M.Si., Ak., CA (Universitas Syiah Kuala)

Dr. Lilis Maryasih, SE., M.Si., Ak., CA (Universitas Syiah Kuala)

Dr. Elvira Luthan, SE., M.Si., Ak., CA (Universitas Andalas Padang)

Dr. Wahyudin Nor, SE., M.Si., Ak., CA, CSRS, CSRA (Universitas Lambung Mangkurat)

Dr. Murhaban, SE., M.Si., Ak., CA (Universitas Malikussaleh)

Dr. Hendra Raza, SE., M.Si., Ak., CA (Universitas Malikussaleh)

Dr. Muammar Khaddafi, SE., M.Si., Ak., CA (Universitas

Malikussaleh)

Dr. Rita Meutia, SE., M.Si., Ak., CA (Universitas Malikussaleh)

Dr. Nazaina, SE., M.Si., Ak., CA (Universitas Malikussaleh)

Dr. Hendra Raza, SE., M.Si., Ak., CA (Universitas Malikussaleh)

Dr. Hilmi, SE., M.Si., Ak., CA (Universitas Malikussaleh)

Dr. Iswadi, SE., M.Si., Ak., CA (Universitas Malikussaleh)

Dr. M. Haykal , SE., M.Si., Ak., CA (Universitas Malikussaleh) 


\section{Daftar Isi}

Menghubungkan CSR Rating, Kinerja Perusahaan dan Nilai 69-78 Perusahaan

Imam Nur Hidayat, Ilham Maulana, Nurita Andriani

DOI:https://doi.org/10.29103/jak.v9i2.3765

Pengaruh Leverage, Penurunan Arus Kas Operasi, Fixed Asset 79-90 Intensity, dan Pertumbuhan Perusahaan Terhadap Keputusan Revaluasi Aset Tetap

Muhammad Haykal, Raudhatul Munira

DOI: https://doi.org/10.29103/jak.v9i2.4682

Analisis Kelayakan Investasi Pembuatan Bagan Apung Baru (Studi

Pada Nelayan Bagan Apung Di Oesapa, Kota Kupang)

Anthon S. Y. Kerihi

DOI: https://doi.org/10.29103/jak.v9i2.3897

Analisis Penerapan Sistem Informasi Pemerintah Daerah (SIPD) Pada Badan Pengelola Keuangan dan Aset Daerah (BPKAD) Kota Medan

Muhammad Irfan Nasution, Nurwani

DOI: https://doi.org/ 10.29103/jak.v9i2.4577

Pengaruh Pendapatan Asli Daerah (PAD) dan Dana Alokasi Khusus 117-128 (DAK) Terhadap Alokasi Belanja Modal Pada Kabupaten/Kota Pemerintah Provinsi Aceh Tahun 2014-2018

Ikhyanuddin, Fuadi Fuadi, Nanda Safitri

DOI: https://doi.org/ 10.29103/jak.v9i2.4732

Pengaruh Sosialisasi Terhadap Efektivitas Penerapan Standar 129-136 Akuntansi Keuangan Entitas Mikro Kecil dan Menengah (SAK EMKM) Di Kota Gorontalo

Mattoasi, Usman, Didiet Pratama Musue

DOI: https://doi.org/ 10.29103/iak.v9i2.3903 